\title{
A revised calendar age for the last reconnection of the Black Sea to the global ocean
}

\author{
G. Soulet ${ }^{\mathrm{a}, \mathrm{b}, *}, \mathrm{G}$. Ménot ${ }^{\mathrm{a}}, \mathrm{G}$. Lericolais ${ }^{\mathrm{b}}$, E. Bard ${ }^{\mathrm{a}}$ \\ ${ }^{a}$ CEREGE, UMR6635, CNRS Université Paul Cézanne Aix-Marseille III, Collège de France, Europôle de l'Arbois, BP 80, 13545 Aix-en-Provence Cedex 04, France \\ ${ }^{\mathrm{b}}$ Ifremer, Centre de Brest, Géosciences Marines BP70, F-29280 PLOUZANE Cedex, France
}

\section{A R T I C L E I N F O}

\section{Article history:}

Received 5 November 2010

Received in revised form

28 February 2011

Accepted 3 March 2011

Available online 29 March 2011

\section{Keywords:}

Black sea

Reconnection

Reservoir age

Bosphorus sill

\begin{abstract}
A B S T R A C T
During the last decade, a debate arose regarding the timing and pattern of the last reconnection of the Black Sea "Lake" with the global ocean. On a geochemical basis, the radiocarbon age of Black Sea "Lake" surface water, during the time of reconnection, was determined to be $\sim 8400{ }^{14} \mathrm{C}$ a. BP. Despite the potential bias induced by the hard water effect in lakes, the reconnection age was calibrated without any reservoir age correction, which led to an estimate of $\sim 9400 \mathrm{cal} \mathrm{a.} \mathrm{BP.} \mathrm{Since} \mathrm{knowledge} \mathrm{for} \mathrm{the} \mathrm{actual}$ calendar age has important hydrologic implications that would provide new insights regarding the mechanism of reconnection, determining the actual calendar age for the last reconnection remains important.

Based upon modeling experiments and micropaleontological reconstructions, the Black Sea "Lake" reconnection occurred in two steps, as follows: 1) Initial Marine Inflow (IMI) followed by 2) a period of increasing basin salinity that led to the Disappearance of Lacustrine Species (DLS). In order to better define the actual calendar age for the last reconnection, a review of the sedimentary expressions of the IMI and DLS boundaries was performed in order to correlate them throughout the Black Sea sedimentary environments. This correlation reconciles the apparent inconsistency in the published radiocarbon dataset, and provides the atmospheric radiocarbon age of the last reconnection, which represents the reference for reservoir age calculations and which can be directly calibrated. We determine reservoir ages for the water column, as well as the reconnection calendar age to be $9000 \mathrm{cal}$ a. BP.

At the reconnection with the global ocean, Black Sea "Lake" reservoir ages were non-negligible and water-depth-dependent, consistent with a weak water column stratification during the Early Holocene. The calibrated age of Initial Marine Inflow (9000 cal a. BP) implies that the former Bosphorus sill was shallower by $\sim 10 \mathrm{~m}$ than is commonly assumed in the literature. Compared to the sedimentary context of the Sakarya coastal plain, this result suggests that the level of the isolated Black Sea was below the former Bosphorus sill depth at the time of the last reconnection. Furthermore, a lag of $\sim 900$ yr between Initial Marine Inflow and the Disappearance of Lacustrine Species indicates that approximately ten centuries were needed to establish the currently observed two-way flow exchange with the global ocean. (C) 2011 Elsevier Ltd. All rights reserved.
\end{abstract}

\section{Introduction}

During the last glacial period, and the associated oceanic lowstand, the Black Sea evolved as a giant freshwater lake (e.g. Stoffers et al., 1978; Schrader, 1979). Water level within the Black Sea "Lake", controlled by regional climate, varied independently from global sea level (e.g. Ross et al., 1970). Early interest in Black Sea geology and climatology was reactivated by a hypothesis of catastrophic

\footnotetext{
* Corresponding author. CEREGE, UMR6635, CNRS Université Paul Cézanne AixMarseille III, Collège de France, Europôle de l'Arbois, BP 80, 13545 Aix-en-Provence Cedex 04, France. Tel.: +33 442507425.

E-mail address: soulet@cerege.fr (G. Soulet).
}

flooding by Mediterranean waters and an associated abrupt water level rise in the Black Sea during the Early Holocene (Ryan et al., 1997). In addition to challenging the previously prevalent consensus of a smooth reconnection (e.g. Ross et al., 1970; Fedorov, 1971), Ryan et al. (1997), and soon after Ryan and Pitman (1998), argued that instantaneous flooding of the vast north-western continental shelf massively displaced Neolithic farmers and imprinted collective memory through culturally-widespread deluge myths. Since the 90 s, an ongoing debate has challenged the validity of the flood hypothesis, as well as its possible cultural consequences (e.g. Görür et al., 2001; Aksu et al., 2002; Ryan et al., 2003; Gökaşan et al., 2005; Hiscott et al., 2007; Yanko-Hombach, 2007; Yanko-Hombach et al., 2007). 
The age of the last Black Sea "Lake" to global ocean reconnection is hotly debated as varying between $7200{ }^{14} \mathrm{C}$ a. BP (Ryan et al., 1997) and $10,000{ }^{14} \mathrm{C}$ a. BP (Aksu et al., 2002). On the basis of a rough comparison of Black Sea geochemical records with the Greenland ice core records, a calendar age of $\sim 8900$ a. BP was recently estimated (Ryan, 2007). New analytical techniques such as the strontium isotope ratio, a powerful water mass tracer, have brought new arguments to the debate and allowed researchers to date the last reconnection to $\sim 8400{ }^{14} \mathrm{C}$ a. BP (Major et al., 2006). However, in order to provide the calendar age of the last reconnection a major issue still remains - the reservoir correction and calibration of the raw ${ }^{14} \mathrm{C}$ date. Bahr et al. (2005) postulated that no reservoir correction was required in order to calibrate the radiocarbon age, leading to a calibrated age for the last reconnection of $\sim 9400$ cal a. BP (e.g. Bahr et al., 2005, 2006, 2008; Major et al., 2006; Kwiecien et al., 2008; Giosan et al., 2009). However, since the reservoir ages of lakes are heavily influenced by the dilution of atmospheric $\Sigma^{14} \mathrm{CO}_{2}$ with "dead" $\Sigma \mathrm{CO}_{2}$ originating from carbonate dissolution within watersheds (Broecker and Olson, 1961; Mangerud, 1972; Andrée et al., 1986; Stein et al., 2004; Kwiecien et al., 2008; Zhou et al., 2009; Ascough et al., 2010), obtaining a reliable date without a reservoir correction is unlikely.

Determining the actual atmospheric radiocarbon age for the last reconnection, and consequently corresponding calendar age, has important implications. An atmospheric radiocarbon age determination would allow us to decipher the reservoir age for the reconnected Black Sea "Lake", and therefore provide new information relating to the basin's hydrologic system. An actual calendar age would also provide new insights into the ongoing reconnection debate. Indeed, during post-glacial global sea level rise, age of the last reconnection depends on the depth of the former Bosphorus sill, which still remains uncertain (e.g. Major et al., 2002; Lambeck et al., 2007; Giosan et al., 2009). The former Bosphorus sill depth has, however, important implications for the glacial-deglacial Black Sea
"Lake" hydrological system, since it controlled maximum lake level and water exchanges. Therefore, constraining the calendar age of the reconnection implies constraining the depth of the former Bosphorus sill, consequently providing useful information in order to better understand the past hydrology of the vanished Black Sea "Lake".

Independent of a catastrophic or a smooth reconnection, modeling experiments (Boudreau and Leblond, 1989; Lane-Serff et al., 1997; Myers et al., 2003; Soulet et al., 2010) and micropaleontological reconstructions (Mudie et al., 2002, 2004; Giunta et al., 2007; Coolen et al., 2009; Marret et al., 2009; Oaie and MelinteDobrinescu, in press), agree on a gradual basin salinization, as well as on the gradual replacement of fresh/brackish biota by marine biota after an initial marine inflow (Mudie et al., 2002; Ryan et al., 2003; Hiscott et al., 2007; Marret et al., 2009). Therefore, we compiled published stratigraphical sequences and radiocarbon ages for the Initial Marine Inflow (IMI) and the Disappearance of Lacustrine Species (DLS) boundaries across the entire basin of the Black Sea (Fig. 1). From our review of reliable published radiocarbon ages, we propose an atmospheric radiocarbon age of $8090 \pm 120{ }^{14} \mathrm{C}$ a. BP for the last reconnection. Knowledge of this atmospheric radiocarbon reference is crucial since it allows the calculation of reservoir ages for two water bodies of the Black Sea "Lake", namely the upper water column ( 0 to $\sim 400 \mathrm{mbsl}$; meters below sea level) and the intermediate water column ( 400 to $1400 \mathrm{mbsl})$. In this manuscript, by calibrating the radiocarbon ages of the reconnection event (IMI) and the Disappearance of Lacustrine Species (DLS), we draw conclusions on the depth of the former Bosphorus sill and on the duration needed for the establishment of the currently observed two-way flow exchange with the global ocean.

\section{The history of the last reconnection of the Black Sea "Lake"}

Both modeling and micropaleontological studies (references above) suggest that after Initial Marine Inflow (IMI), the Black Sea

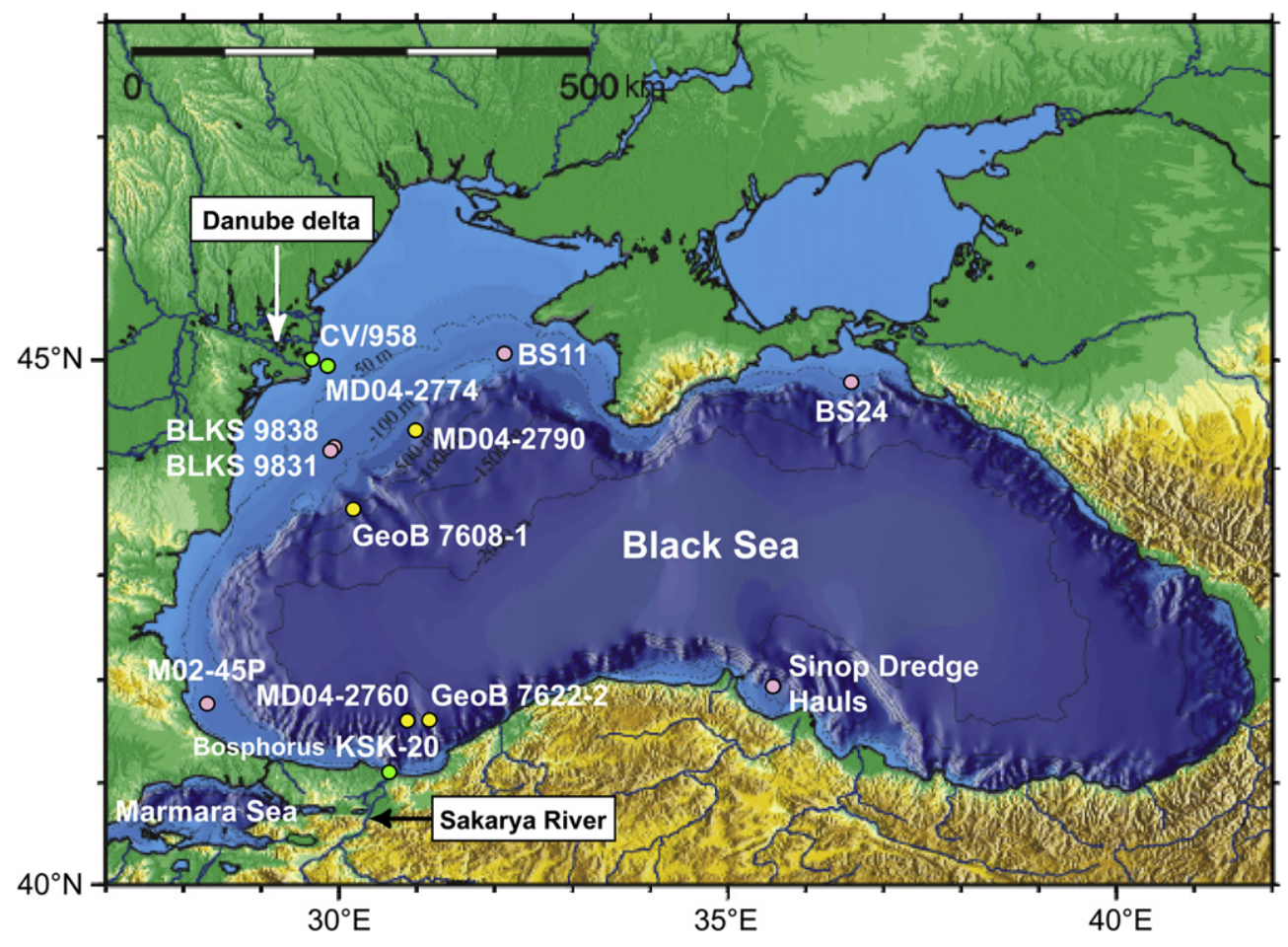

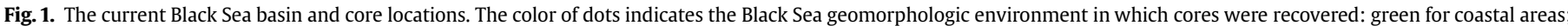
pink for shelf; yellow for slope and basin. Core references are provided in Table 1, except for cores CV/958 and MD04-2774 for which references are provided in Section 2.1.3. 
basin salinization occurred gradually, leading to the progressive Disappearance of Lacustrine Species (DLS) and the replacement of fresh/brackish biota by marine biota. Sedimentary expressions of the IMI and DLS boundaries are expected to be different depending upon the Black Sea "Lake" sedimentary environment - the basin, the slope, the continental shelf, and the coastal area (Fig. 1). Published datasets are spread across the entire basin. Until now, no study has gathered and correlated the various sedimentary expressions of the last reconnection across the entire basin. In this section, we provide a synthesis of the different sedimentary expressions and the radiocarbon ages for the IMI and DLS boundaries across the entire basin (Fig. 2).

\subsection{Sedimentary expressions of the last lacustrine to marine transition across the Black Sea basin}

\subsubsection{Basin and slope}

Late Quaternary sediments of the Black Sea are commonly subdivided into three units (e.g. Ross and Degens, 1974). The uppermost units, Units I and II, represent the last marine stage of the Black Sea. Unit I is characterized by thin coccolith-rich layers. Unit II conformably underlying Unit I is a sapropel characterized by a dark olive green to dark brown thinly laminated mud. Below Unit II is limnic Unit III which represents the last lacustrine stage of the Black Sea (e.g. Ross and Degens, 1974).

Initial Marine Inflow (IMI) is spectacularly recorded within slope and basin sedimentary records by highly-sensitive geochemical proxies (the ${ }^{87} \mathrm{Sr} /{ }^{86} \mathrm{Sr}$, the $\mathrm{Mg} / \mathrm{Ca}$, and the $\mathrm{Sr} / \mathrm{Ca}$ of carbonate shells) with an instantaneous change from lacustrine to marine signatures (Major et al., 2006; Bahr et al., 2008) (Fig. 3). These changes occur concomitantly with a sharp decrease in the sediment carbonate content (Major et al., 2002; Bahr et al., 2005, 2006, 2008; Kwiecien et al., 2008), as well as with a sudden increase in sediment grain size (Major et al., 2002; Bahr et al., 2005) and XRF-Ti/Ca (Bahr et al., 2005) (Fig. 3).

The onset of Unit II (sapropel) is characterized by the occurrence of thinly laminated layers rich in aragonite crystals (e.g. Ross and Degens, 1974; Giunta et al., 2007; Kwiecien et al., 2008) and by a sharp increase in Total Organic Carbon (Bahr et al., 2008) (Fig. 3). In several cores obtained from the NW-slope and from the deep basin, marine coccolithophores appear concomitantly with aragonite layers (Giunta et al., 2007; Coolen et al., 2009), while fresh to brackish ostracods or bivalves persist in the sediments until the appearance of aragonite layers (Major et al., 2002; Bahr et al., 2005, 2006, 2008; Kwiecien et al., 2008). Therefore, aragonite layers represent the Disappearance of Lacustrine Species (DLS). Hence, between the IMI and the DLS a sedimentary layer was deposited (Figs. 2 and 3) which indicates the transition from a fresh/brackish to a marine environment (e.g. Ryan et al., 2003; Giunta et al., 2007).

\subsubsection{Continental shelf}

In the literature, three units are similarly described for the recent sediments of the continental shelf. However, the terminology is not similar to that used for basin and slope sedimentary sequences, and the stratigraphic positions of the IMI and the DLS boundaries are not fully described.

Shcherbakov and Babak (1979) classified the sedimentary sequence of the NW continental shelf in three units. The first two units named Modiolus mud and Mytilus mud are rich in marine bivalves (Modiolus phaseolinus and Mytilus galloprovincialis, respectively). The last unit, conformably underlying these two units is named Dreissena mud, rich in freshwater to brackish bivalves (Dreissena rostriformis).

\section{Coastal Plain}

(Sakarya example) NW Continental Shelf Slope and Deep Basin

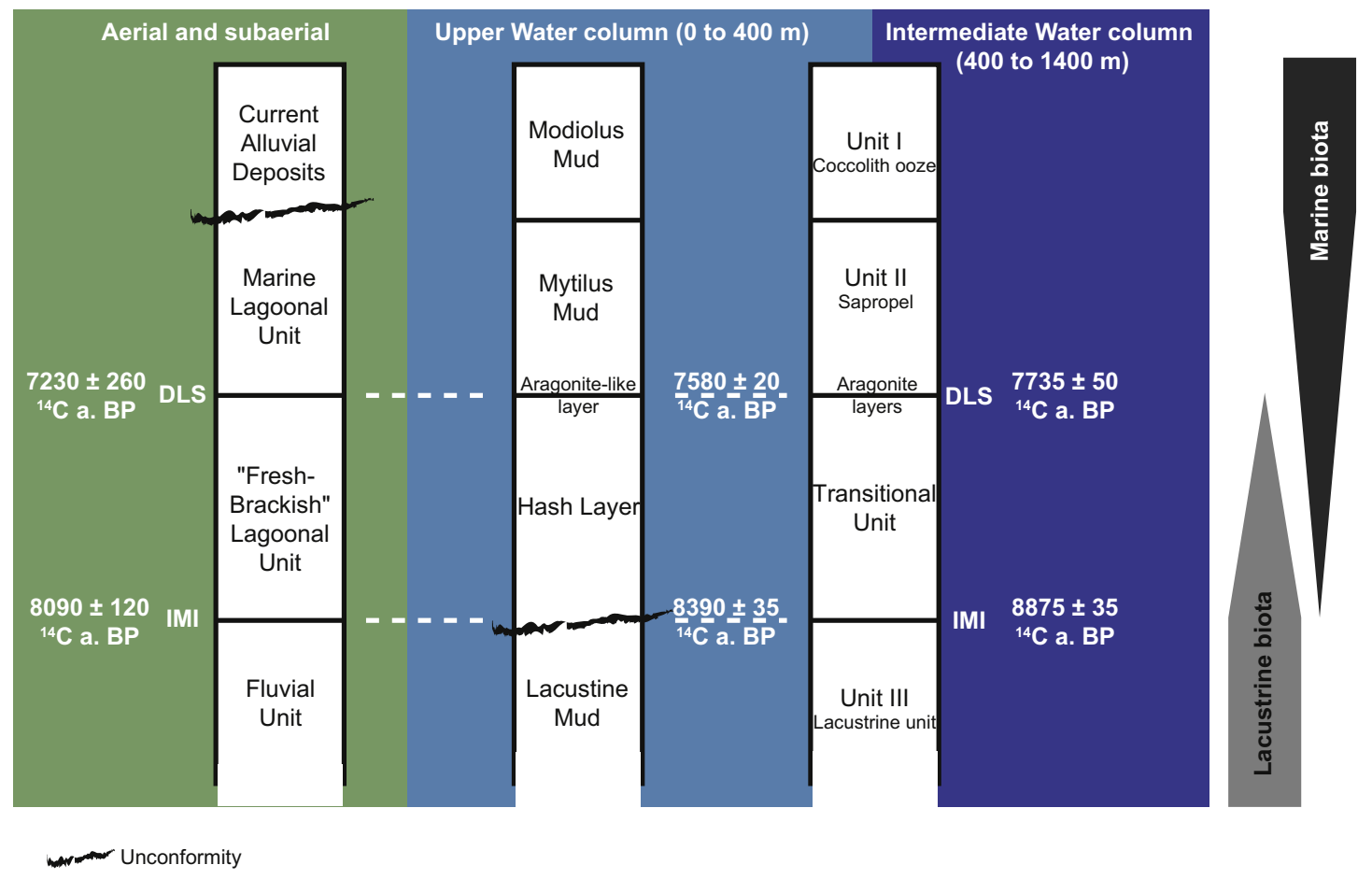

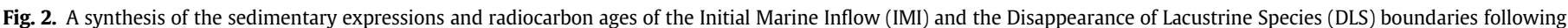

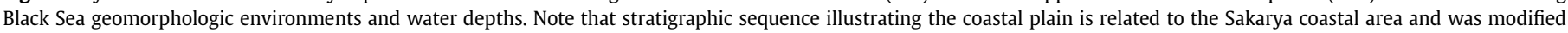
after Görür et al. (2001) (borehole KSK-20 in Fig. 1). 


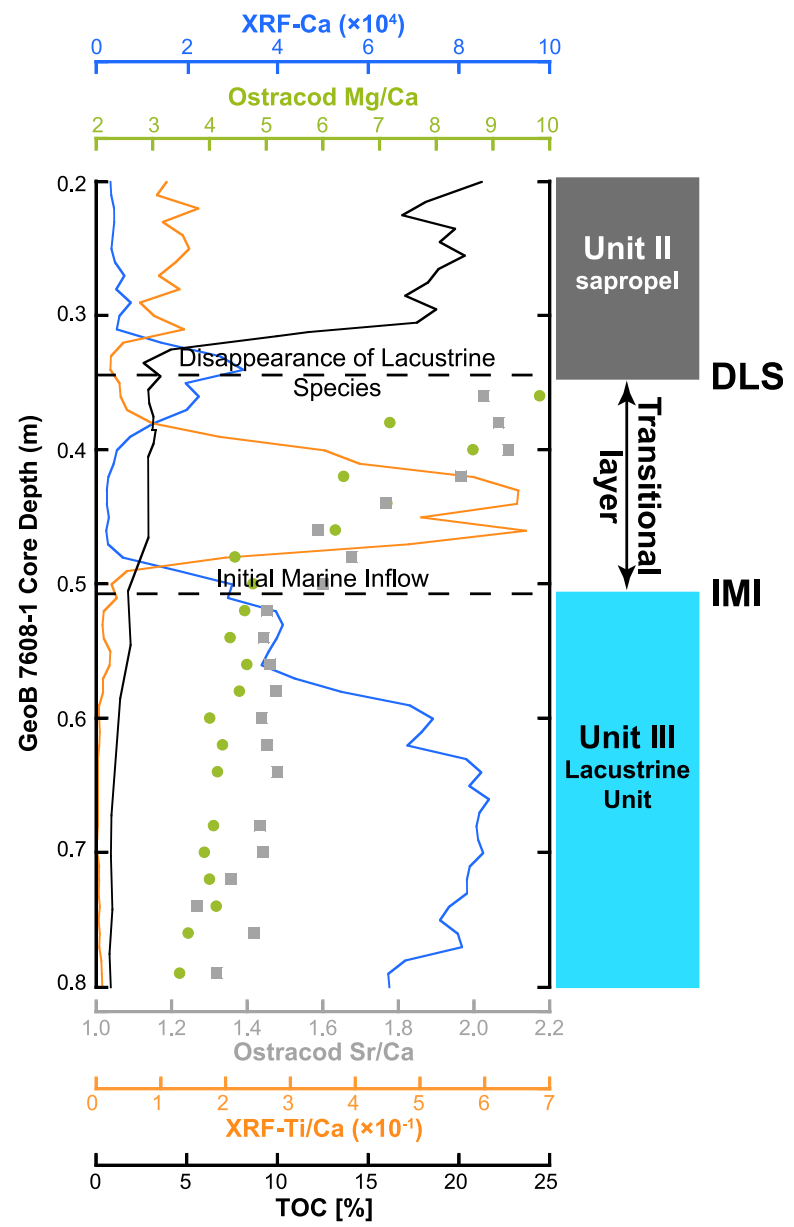

Fig. 3. An example of the lacustrine to marine transition from the basin-retrieved sediment core GeoB 7608-1 (Bahr et al., 2005, 2006, 2008). The Initial Marine Inflow (IMI boundary) is characterized by a steep decrease in XRF-Ca intensity concomitant with a peak in XRF-Ti/Ca (also indicated by a peak in the sediment grain size, not shown here), as well as a drastic increase in ostracod $\mathrm{Mg} / \mathrm{Ca}$ and $\mathrm{Sr} / \mathrm{Ca}$. Total Organic Carbon also gently increases. The Disappearance of the Lacustrine Species (the DLS boundary) is characterized by the disappearance of brackish ostracods (i.e. no data for $\mathrm{Mg} / \mathrm{Ca}$ and $\mathrm{Sr} / \mathrm{Ca}$ ), by an increase in XRF-Ca possibly reflecting the occurrence of the Aragonite Layers, and by a significant overall increase in Total Organic Carbon reflecting the onset of the sapropel deposition.

The Dreissena mud unit unconformably overlies stiff barren muds on the mid-shelf ( $>92 \mathrm{~m}$ to at least $28 \mathrm{~m}$ in water depth) or Dreissena-bearing muds in the outer shelf (Ryan et al., 1997, 2003; Major et al., 2006; Giunta et al., 2007; Lericolais et al., 2007, 2009, 2010; Oaie and Melinte-Dobrinescu, in press), and bears more diverse salinity tolerant assemblages of molluscs (Ryan et al., 2003) and dinocysts (Mudie et al., 2004) than older sedimentary units. The unit, termed the "hash layer" in the literature, represents the last lacustrine to marine transition (Ryan et al., 1997, 2003; Major et al., 2006; Lericolais et al., 2007, 2009). Interestingly, the "hash layer" is topped by a peculiar layer rich in aragonite-like crystals (Giunta et al., 2007; Oaie and Melinte-Dobrinescu, in press) which could be equivalent to the aragonite layers typical of the onset of Unit II in slope and basin sedimentary environments (DLS boundary). Therefore, the base and top of the "hash layer" likely represent the IMI and the DSL boundaries, respectively (Fig. 3).

\subsubsection{Coastal settings}

Sea level reconstruction in the Danube delta is now rather well constrained at least since the middle Holocene (Giosan et al., 2006).
In an attempt to decipher the evolution of older Early Holocene deltaic-estuarine phases, the Danube delta was recently cored onshore (core CV/958; Giosan et al., 2009) and offshore (core MD04-2774; Lericolais et al., 2010) (Fig. 1). In both cores, fluvial deposits of Early Holocene age (Lericolais et al., 2010) were found to be overlain by deltaic front facies deposited in lacustrine settings (Giosan et al., 2009). The deltaic front itself is overlain by marine sediments (Giosan et al., 2009; Lericolais et al., 2010). Giosan et al. (2009) showed that marine sediments unconformably overlie the earlier lacustrine sequence, whereas the scarcity of radiocarbon ages provided by Lericolais et al. (2010) prevented us from determining the IMI and the DLS boundaries that characterized the last lacustrine to marine transition in the Danube delta.

In the SW Black Sea coast, Görür et al. (2001) described a transect of boreholes drilled in the coastal plain near the mouth of the Sakarya River (Fig. 1). The base of the sedimentary sequence is characterized by fluvial sediments conformably overlain by lacustrine clay to sand sediments. The lacustrine sediments contain fresh to brackish fauna as well as fluvial gastropods and peats, suggesting a lagoonal marshy environment. The lacustrine facies grades upward into lagoonal and marshy deposits, characterized by alternating layers of clay, silt, and sand mixed with peat layers and Mediterranean fauna. The fresh/brackish lagoonal deposits conformably overlying the fluvial deposits of the Sakarya River (Fig. 2) were initially interpreted as representing a high-stand of the Black Sea "Lake" (Görür et al., 2001). In other words, authors suggested that Black Sea "Lake" was flowing into the Marmara Sea at the time of its reconnection to Mediterranean Sea. Contrary to modeling experiments (Boudreau and Leblond, 1989; Lane-Serff et al., 1997; Myers et al., 2003; Soulet et al., 2010) and micropaleontological reconstructions (Mudie et al., 2002, 2004; Giunta et al., 2007; Coolen et al., 2009; Marret et al., 2009; Oaie and MelinteDobrinescu, in press) agreeing on a gradual basin salinization, Görür et al. (2001)'s interpretation does not imply such a transitional hydrologic state between the isolated and reconnected Black Sea as recorded, however, in each sedimentary environment of the Black Sea (Transitional Unit in the slopes and the basin, Figs. 2 and 3; "Hash Layer" in the shelf, Fig. 2). Since such a transitional hydrologic state should have been recorded in Black Sea coastal areas as well, sediments deposited under fresh/brackish lagoonal conditions in the former Sakarya coastal plain are likely to represent this transitional state. Therefore, transitions from the fluvial plain to a fresh/brackish lagoon and from the fresh/brackish lagoon to a marine lagoon are likely to represent the IMI and the DLS boundaries, respectively (Fig. 2).

\subsection{Radiocarbon ages of the last lacustrine to marine transition}

Following the mapping of the Initial Marine Inflow (IMI) and the Disappearance of Lacustrine Species (DLS) from the Black Sea deep basin to the coast (Fig. 2), we compiled the reliable radiocarbon ages for these boundaries published in recent studies (Ballard et al., 2000; Görür et al., 2001; Major et al., 2002; Bahr et al., 2005; Lamy et al., 2006; Hiscott et al., 2007; Kwiecien et al., 2008; Marret et al., 2009; this study) (Fig. 2, Table 1).

Based upon inter-comparisons of geochemical records on cores retrieved at different water depths, Bahr et al. $(2005,2006)$ showed that the water column was stratified from $\sim 15 \mathrm{cal} \mathrm{a}$. BP until the last reconnection (IMI boundary). Following these results and in agreement with Kwiecien et al. (2008), the water column as well as the corresponding compiled radiocarbon ages (Table 1) were divided into two main groups (intermediate water column, $\sim 400$ to $\sim 1400 \mathrm{mbsl}$; and upper water column, 0 to $\sim 400 \mathrm{mbsl}$ ). A third group contains atmospheric radiocarbon ages (Table 1 ). The IMI and DLS boundaries were dated to $8875 \pm 35(n=2)$ and $7735 \pm 50$ 
Table 1

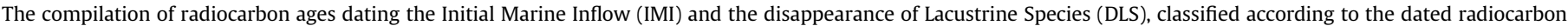
reservoir. Reservoir ages are calculated by subtracting the DLS/IMI atmospheric radiocarbon age from the DLS/IMI radiocarbon age of the water body.

\begin{tabular}{|c|c|c|c|c|c|c|c|}
\hline Reference & Core & $\begin{array}{l}\text { Sample } \\
\text { code }^{\mathrm{a}}\end{array}$ & $\begin{array}{l}\text { Dated } \\
\text { material }\end{array}$ & $\begin{array}{l}\text { Dated } \\
\text { boundary }\end{array}$ & $\begin{array}{l}\text { Selection } \\
\text { criterion }\end{array}$ & $\begin{array}{l}\text { Radiocarbon } \\
\text { Age }\left({ }^{14} \mathrm{C} \text { a. } \mathrm{BP}\right)^{\mathrm{b}}\end{array}$ & $\begin{array}{l}\text { Sample reservoir } \\
\text { age }\left({ }^{14} \mathrm{C} \text { yr }\right)^{\mathrm{c}}\end{array}$ \\
\hline \multicolumn{8}{|l|}{ Atmosphere } \\
\hline Görür et al. (2001) & KSK-20 & - & Peat Layer & DLS & Stratigraphic review & $7230 \pm 260$ & - \\
\hline Görür et al. (2001) & KSK-20 & - & Wood & IMI & Stratigraphy review & $8090 \pm 120$ & - \\
\hline \multicolumn{8}{|c|}{ Surface water - upper water column (0-400 m water depth) } \\
\hline Ballard et al. (2000) & Dredge Hauls & OS-21659 & Turricaspia caspia lincta & DLS & Youngest limnic biota & $7460 \pm 55$ & $230 \pm 266$ \\
\hline Ballard et al. (2000) & Dredge Hauls & OS-21660 & Turricaspia caspia lincta & DLS & Youngest limnic biota & $7590 \pm 55$ & $360 \pm 266$ \\
\hline Ballard et al. (2000) & Dredge Hauls & OS-21661 & Turricaspia caspia lincta & DLS & Youngest limnic biota & $7480 \pm 55$ & $250 \pm 266$ \\
\hline Lamy et al. (2006) & GeoB 7622-2 & KIA-25753 & $\begin{array}{l}\text { Mytilus galloprovincialis } \\
\text { larval stage }\end{array}$ & DLS & Onset of sapropel & $7625 \pm 55$ & $395 \pm 266$ \\
\hline $\begin{array}{l}\text { Hiscott et al. }(2007,2010) \\
\quad \text { Marret et al. }(2009,2010)\end{array}$ & M02-45P & TO-11438 & Monodacna pontica & DLS & $\begin{array}{l}\text { Geochemistry and } \\
\text { palynology }\end{array}$ & $7560 \pm 60$ & $330 \pm 267$ \\
\hline \multirow[t]{2}{*}{ This study ${ }^{\mathrm{d}}$} & MD04-2790 & SacA 13276 & Ostracods & DLS & Onset of sapropel & $7640 \pm 30$ & $410 \pm 262$ \\
\hline & & & & & & $\begin{array}{l}\text { DLS weighted } \\
\text { mean } \\
7580 \pm 20\end{array}$ & $\begin{array}{l}\text { DLS mean } \\
\text { reservoir age } \\
350 \pm 260\end{array}$ \\
\hline Major et al. (2006) & BLKS9838 & ETH-22159 & Dreissena sp. & IMI & $\begin{array}{l}\text { Oldest biota with } \\
\text { marine }{ }^{87} \mathrm{Sr} /{ }^{86} \mathrm{Sr}\end{array}$ & $8275 \pm 70$ & $185 \pm 139$ \\
\hline Major et al. (2006) & BLKS9831 & ETH-22158 & Dreissena sp. & IMI & $\begin{array}{l}\text { Oldest biota with } \\
\text { marine }{ }^{87} \mathrm{Sr} /{ }^{86} \mathrm{Sr}\end{array}$ & $8360 \pm 75$ & $270 \pm 142$ \\
\hline Major et al. (2006) & BS11 & ETH-23747 & Dreissena sp. & IMI & $\begin{array}{l}\text { Oldest biota with } \\
\text { marine }{ }^{87} \mathrm{Sr} /{ }^{86} \mathrm{Sr}\end{array}$ & $8415 \pm 70$ & $325 \pm 139$ \\
\hline Major et al. (2006) & BS24 & ETH-23753 & Dreissena polymorpha & IMI & $\begin{array}{l}\text { Oldest biota with } \\
\text { marine }{ }^{87} \mathrm{Sr} /{ }^{86} \mathrm{Sr}\end{array}$ & $8550 \pm 80$ & $460 \pm 144$ \\
\hline \multirow[t]{3}{*}{$\begin{array}{l}\text { Hiscott et al. (2007) } \\
\quad \text { Marret et al. (2009) }\end{array}$} & M02-45P & TO-11142 & Truncatella subcylindrica & IMI & $\begin{array}{l}\text { Geochemistry and } \\
\text { palynology }\end{array}$ & $8380 \pm 70$ & $290 \pm 139$ \\
\hline & & & & & & $\begin{array}{l}\text { IMI weighted } \\
\text { mean }\end{array}$ & $\begin{array}{l}\text { IMI mean } \\
\text { reservoir age }\end{array}$ \\
\hline & & & & & & $8390 \pm 35$ & $300 \pm 125$ \\
\hline \multicolumn{8}{|c|}{ Intermediate water column (400-1400 m water depth) } \\
\hline \multirow[t]{2}{*}{ Bahr et al. (2005) } & GeoB 7608-1 & KIA-21464 & Ostracods & DLS & Onset of sapropel & $7735 \pm 50$ & $505 \pm 265$ \\
\hline & & & & & & $\begin{array}{l}\text { DLS weighted } \\
\text { mean } \\
7735 \pm 50\end{array}$ & $\begin{array}{l}\text { DLS mean } \\
\text { reservoir age } \\
505 \pm 265\end{array}$ \\
\hline Kwiecien et al. (2008) & MD04-2760 & KIA-26699 & Gastropods & IMI & $\begin{array}{l}\text { Steep decrease in } \\
\text { XRF-Ca intensity }\end{array}$ & $8820 \pm 55$ & $730 \pm 132$ \\
\hline \multirow[t]{3}{*}{ Kwiecien et al. (2008) } & MD04-2760 & KIA-25679 & Ostracods & IMI & $\begin{array}{l}\text { Steep decrease in } \\
\text { XRF-Ca intensity }\end{array}$ & $8910 \pm 45$ & $820 \pm 128$ \\
\hline & & & & & & $\begin{array}{l}\text { IMI weighted } \\
\text { mean }\end{array}$ & $\begin{array}{l}\text { IMI mean } \\
\text { reservoir age }\end{array}$ \\
\hline & & & & & & $8875 \pm 35$ & $785 \pm 125$ \\
\hline
\end{tabular}

${ }^{a}$ Görür et al. (2001) did not provide the sample code but indicated that the measurements were carried out by Geochron Laboratories.

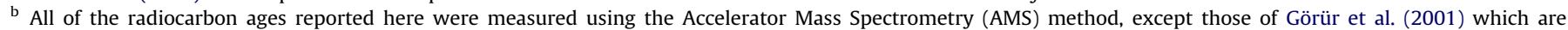
conventional datings corrected for $\delta^{13} \mathrm{C}$.

c Uncertainties are propagated using the partial derivative theory.

d Sample of monospecific Candona sp. picked just below the aragonite layer in core MD04-2790 (44 ${ }^{\circ} 12.8^{\prime} \mathrm{N}, 30{ }^{\circ} 59.6 ’ \mathrm{E}$; 352 mbsl). Measurement was performed by Accelerator Mass Spectrometry at the "Laboratoire de Mesure du Carbone 14" in Saclay, France.

$(n=1){ }^{14} \mathrm{C}$ a. BP for the intermediate water column, and $8390 \pm 35$ $(n=5)$ and $7580 \pm 20(n=6){ }^{14} \mathrm{C}$ a. BP for the upper water column, respectively (reported ages are weighted means by variance; Table 1). A piece of wood dated to $8090 \pm 120{ }^{14} \mathrm{C}$ a. BP displays the IMI atmospheric radiocarbon age, while a DLS atmospheric age of $7230 \pm 260{ }^{14} \mathrm{C}$ a. BP is provided by a peat layer (Görür et al., 2001) (Table 1). The last two radiocarbon ages are fundamental since they represent atmospheric references for reservoir age calculations and, once calibrated, the calendar ages of the two major transitions that characterized the last reconnection Black Sea.

\section{Reservoir age at the last reconnection}

The reservoir age of any water mass reflects the difference between its radiocarbon content and the contemporary atmospheric radiocarbon content, with the water mass always being depleted in radiocarbon (e.g. Arnold and Anderson, 1957; Craig, 1957; Suess and Revelle, 1957; Stuiver and Polach, 1977; Bard, 1988). The resulting effect is that the radiocarbon age of a water body is systematically older than the contemporary atmospheric radiocarbon age. Therefore, we calculated the reservoir age for each of the compiled radiocarbon ages by subtracting the atmospheric radiocarbon age of the boundary they date (Table 1 ).

At the time of the reconnection (IMI) and the disappearance of fresh to brackish biota (DLS), the upper water column showed similar reservoir ages $\left(300 \pm 125\right.$ and $350 \pm 260{ }^{14} \mathrm{C}$ yr, respectively, Table 1 ), in rough agreement with a previous reservoir age estimations (Ryan, 2007). However, our results are in disagreement with previous studies that inferred a negligible reservoir age (Bahr et al., 2005; Kwiecien et al., 2008). The discrepancy could be due to the use of an unsuitable reference value in the latter studies.

At the reconnection (IMI boundary), reservoir age calculated for the intermediate water column is larger compared to reservoir age for upper water column $\left(785 \pm 125\right.$ against $300 \pm 125{ }^{14} \mathrm{C} \mathrm{yr}$, respectively, Table 1 ), in agreement with recent reservoir age estimations (Kwiecien et al., 2008). Recent studies based upon geochemical data (Bahr et al., 2006, 2008) suggest water column stratification at least at the Initial Marine Inflow (IMI boundary). 
According to Bahr et al. (2006, 2008), the water stratification persisted since the onset of the Bølling-Allerød period, due to climatedriven evaporation during the last 6 millennia preceding the last reconnection (15-9 cal ka. BP). Geochemical records $\left(\delta^{18} \mathrm{O}\right.$ and $\mathrm{Mg}$ / $\mathrm{Ca}$ and $\mathrm{Sr} / \mathrm{Ca}$ obtained on ostracods) suggest then a sudden homogenization of the water column between IMI and DLS boundaries, likely driven by the saline intrusion of marine waters into the Black Sea (Bahr et al., 2006, 2008). Reservoir ages of upper $\left(350 \pm 260{ }^{14} \mathrm{C}\right.$ yr $)$ and intermediate $\left(505 \pm 265{ }^{14} \mathrm{C} \mathrm{yr}\right)$ water columns are statistically undistinguishable at the DLS boundary and therefore support a homogenous water column during the Black Sea transitional state between fresh/brackish to marine.

\section{The calendar age of the last reconnection - implications for the Black Sea hydrologic system}

Once reliable atmospheric radiocarbon ages for the IMI and the DLS boundaries are known, calendar ages can be determined by utilizing the most recent calibration curve (Reimer et al., 2009), which lead to ages of $8995 \pm 145$ and $8080 \pm 250$ cal a. BP, respectively. Apparently, the salinity threshold needed to eradicate fresh/brackish biota was reached slowly ( $900 \mathrm{yr}$ ), reflecting a slow Black Sea salinization in accordance with the conclusions of recent studies (e.g. Ryan et al., 2003; Hiscott et al., 2007; Marret et al., 2009; Soulet et al., 2010).

Overall, the calendar age of the reconnection (IMI boundary) is crucial for deciphering the former Bosphorus sill depth and subsequent implications in the ongoing reconnection debate, and for evaluating the involvement of the catastrophic drainage of the ice-dammed lake Agassiz-Ojibway in the Black Sea "Lake" reconnection, as recently postulated (Turney and Brown, 2007).

\subsection{Catastrophic drainage of lake Agassiz-Ojibway and Black Sea "Lake" reconnection}

Recently, the last Black Sea "Lake" reconnection was suggested to have occurred between 8350 and $8230 \mathrm{cal}$ a. BP (Turney and Brown, 2007) leading to the hypothesis that the catastrophic drainage of the former ice-dammed lake Agassiz-Ojibway $\sim 8470$ a. ago (Barber et al., 1999) and associated $1.4 \mathrm{~m}$ sea level rise, triggered this last reconnection. Our results suggest that the last reconnection, dated to $8995 \pm 145 \mathrm{cal}$ a. BP, preceded by $\sim 500 \mathrm{yr}$ the catastrophic drainage of the ice-dammed lake Agassiz-Ojibway. The discrepancy comes from the fact that Turney and Brown (2007) constrained the maximum age of the last reconnection by using the youngest fresh/brackish mollusc reported in the literature (7460 $\pm 55{ }^{14} \mathrm{C}$ a. BP; Ballard et al., 2000) whereas the first dated fresh/brackish mollusc displaying a ${ }^{87} \mathrm{Sr} /{ }^{86} \mathrm{Sr}$ ratio typical for marine water signature was $\sim 1000{ }^{14} \mathrm{C}$ yr older $\left(8550 \pm 80{ }^{14} \mathrm{C}\right.$ a. $\mathrm{BP}$; Major et al., 2006). This invalidates a trigger of the Black Sea "Lake" reconnection by the catastrophic drainage of ice-dammed lake Agassiz-Ojibway.

\subsection{The Marmara Sea gateway two-way flow establishment and the former Bosphorus sill depth}

In basin and slope sedimentary environments, the DLS boundary corresponds to both the Disappearance of Lacustrine Species (e.g. the disappearance of Candona sp. ostracods, see Fig. 3) and to the onset of sapropel deposition (Fig. 3). The DLS boundary occurs $900 \mathrm{yr}$ latter, after Initial Marine Inflow (IMI boundary), indicating that, whatever the mechanism of the reconnection (smooth or abrupt), the establishment of the twoway flow that currently characterizes the Marmara Sea gateway occurred gradually in response to a slow, but continuous, salinity increase and attendant density differentiation in deep waters of the Black Sea.

An interesting by-product of our review of reconnection radiocarbon ages is that we are able to constrain the depth of the Bosphorus sill, a key player in the history of the reconnection (Fig. 4). Indeed, during post-glacial global sea level rise, the timing of the first marine water intrusion into the Black Sea was only controlled by the Bosphorus sill depth. Determining the age of IMI boundary implies estimating the Bosphorus sill depth at the time of the reconnection. Based upon the sea level curve model for the Marmara Sea gateway, from the Dardanelles to the Bosphorus Straits, which takes into account isostatic theory and regional sea level data from the Mediterranean Sea (Lambeck et al., 2007), we determined that the Bosphorus sill depth was $23 \pm 5 \mathrm{mbsl}$ at the time of the reconnection (IMI boundary; $8960 \pm 185$ cal a. BP). In studies related to the Black Sea reconnection, a Bosphorus sill depth of $\sim 30$ to $35 \mathrm{~m}$ in water depth, corresponding to the current sill depth, is commonly assumed. Therefore, our results suggest that the sill depth was $\sim 10 \mathrm{~m}$ shallower than commonly assumed (e.g. Ryan et al., 1997; Hiscott et al., 2007; Giosan et al., 2009).

Finally, the depth of the Bosphorus sill also corresponds to the upper limit of the Black Sea level during its isolated phase. If the Black Sea was outflowing into the Marmara Sea as suggested by several workers (e.g. Görür et al., 2001; Aksu et al., 2002; Hiscott et al., 2007), its level would have inevitably been higher than the former Bosphorus sill depth. In the Sakarya coastal plain, the fresh/ brackish lagoonal sedimentary environment described by Görür et al. (2001), which we interpreted as representing the transition between the Black Sea lacustrine and marine states, lies at $28 \mathrm{mbsl}$ conformably on fluvial deposits of the Sakarya River. This suggests that prior to the last reconnection, the level of the isolated Black Sea was below the Bosphorus sill depth. Therefore, at the time of the reconnection, the isolated Black Sea could not have been

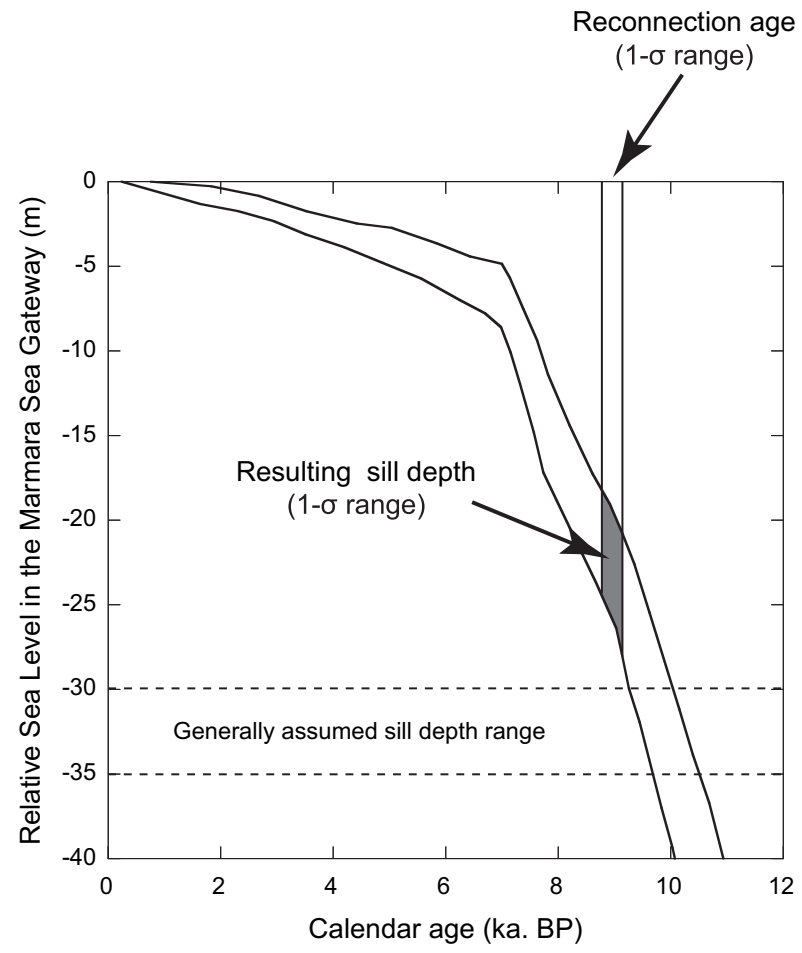

Fig. 4. Predicted relative sea level for the Marmara Sea gateway (from Lambeck et al., 2007) and the resulting Bosphorus sill depth (gray area) for the last reconnection (the IMI boundary). 
outflowing into the Marmara Sea. This observation is in agreement with recent results from the Danube delta (Giosan et al., 2009).

\section{Conclusions}

Our approach provides the atmospheric radiocarbon age of the last Black Sea "Lake" reconnection and consequently a reference for calculating the reservoir age of the Black Sea "Lake". Contrary to previous assumptions (e.g. Bahr et al., 2005; Kwiecien et al., 2008), our results suggest that the reservoir age was not negligible in the upper water column. Our results also reconcile the apparent inconsistency in the published radiocarbon dataset, an inconsistency likely due to differences in reservoir ages throughout the Black Sea "Lake" water column. Our synthesis improves the chronology of the last reconnection, occurring at $8995 \pm 145 \mathrm{cal}$ a. BP. This finding shows that the reconnection was not related to catastrophic drainage of the ice-dammed lake Agassiz-Ojibway. We also show that the replacement of lacustrine biota by marine biota occurred in about $900 \mathrm{yr}$, a time slice required for the onset of the two-way flow circulation currently observed in the Marmara Sea gateway. Finally, our results imply estimating the former sill depth of the Bosphorus strait to $23 \pm 5 \mathrm{~m}$ in water depth. Compared to the sedimentary context of the Sakarya coastal plain, this result suggests that the level of the isolated Black Sea was below the former Bosphorus sill depth. Further sedimentological investigations in coastal areas, as well as new radiocarbon ages on terrestrial remains are required to strengthen the validity of our approach.

\section{Acknowledgments}

Our paper is a contribution to the ASSEMBLAGE project funded by the European Commission (EVK3-CT-2002-00090). We thank A. Crespy for help with Fig. 1 and W. Roest for manuscript editing. We thank the two anonymous reviewers for their constructive comments. We thank the Artemis project for the precious radiocarbon measurement. We are grateful to CNRS, Ifremer, and the Collège de France for providing salary support to G. Soulet. Paleoclimate work at CEREGE is supported by grants from the Gary Comer Foundation for Science and Education, the European Community (Project Past4Future), the CNRS-INSU (BLACKMED project), and the Collège de France.

\section{References}

Aksu, A., Hiscott, R.N., Mudie, P., Rochon, A., Kaminski, M.A., Abrajano, T., Yasar, D., 2002. Persistent Holocene outflow from the Black Sea to the eastern Mediterranean contradicts Noah's flood hypothesis. GSA Today 12, 4-10.

Andrée, M., Oeschger, H., Siegenthaler, U., Riesen, T., Moell, M., 1986. ${ }^{14} \mathrm{C}$ dating of plant macrofossils in lake sediment. Radiocarbon 28, 411-416.

Arnold, J.R., Anderson, E.C., 1957. The distribution of radiocarbon in nature. Tellus 9, $28-32$.

Ascough, P.L., Cook, G.T., Church, M.J., Dunbar, E., Einarsson, Á, McGovern, T.H., Dugmore, A.J., Perdikaris, S., Hastie, H., Friðriksson, A., Gestsdóttir, H., 2010 Temporal and spacial variations in freshwater ${ }^{14} \mathrm{C}$ reservoir effects: lake Mývatn, Northern Iceland. Radiocarbon 52, 1098-1112.

Barber, D.C., Dyke, A., Hillaire-Marcel, C., Jennings, A.E., Andrews, J.T., Kerwin, M.W., Bilodeau, G., McNeely, R., Southon, J., Morehead, M.D., Gagnon, J.M., 1999 Forcing of the cold event of 8200 years ago by catastrophic drainage of Laurentide lakes. Nature 400, 344-348.

Bahr, A., Arz, H.W., Lamy, F., Wefer, G., 2006. Lateglacial to Holocene paleoenvironmental evolution of the Black Sea, reconstructed with stable oxygen isotope records obtained on ostracod shells. Earth and Planetary Science Letters 241, $863-875$.

Bahr, A., Lamy, F., Arz, H., Kuhlmann, H., Wefer, G., 2005. Lateglacial to Holocene climate and sedimentation history in the NW Black Sea. Marine Geology 214, 309-322.

Bahr, A., Lamy, F., Arz, H.W., Major, C., Kwiecien, O., Wefer, G., 2008. Abrupt changes of temperature and water chemistry in the late Pleistocene and early Holocene Black Sea. Geochemistry Geophysics Geosystems 9. doi:10.1029/2007GC001683 Q01004.

Ballard, R.D., Coleman, D.F., Rosenberg, G.D., 2000. Further evidence of abrupt Holocene drowning of the Black Sea shelf. Marine Geology 170, 253-261.
Bard, E., 1988. Correction of accelerator mass spectrometry ${ }^{14} \mathrm{C}$ ages measured in Planktonic Foraminifera: paleoceanographic implications. Paleoceanography 3, 635-645.

Boudreau, B.P., Leblond, P.H., 1989. A simple evolutionary model for water and salt in the Black Sea. Paleoceanography 4, 157-166.

Broecker, W.S., Olson, E.A., 1961. Lamont radiocarbon measurements VIII. Radiocarbon 3, 176-204.

Coolen, M.J.L., Saenz, J.P., Giosan, L., Trowbridge, N.Y., Dimitrov, P., Dimitrov, D., Eglinton, T.I., 2009. DNA and lipid molecular stratigraphic records of haptophyte succession in the Black Sea during the Holocene. Earth and Planetary Science Letters 284, 610-621.

Craig, H., 1957. The natural distribution of radiocarbon and the exchange time of carbon dioxide between atmosphere and sea. Tellus 9, 1-17.

Fedorov, P.V., 1971. Postglacial transgression of the Black Sea. International Geology Review 14, 160-164.

Giosan, L., Donnelly, J.P., Constantinescu, S., Filip, F., Ovejanu, I., VespremeanuStroe, A., Vespremeanu, E., Duller, G.A.T., 2006. Young Danube delta documents stable Black Sea level since the middle Holocene: morphodynamic, paleogeographic, and archaeological implications. Geology 34, 757-760.

Giosan, L., Filip, F., Constatinescu, S., 2009. Was the Black Sea catastrophically flooded in the early Holocene? Quaternary Science Reviews 28, 1-6.

Giunta, S., Morigi, C., Negri, A., Guichard, F., Lericolais, G., 2007. Holocene biostratigraphy and paleoenvironmental changes in the Black Sea based on calcareous nannoplankton. Marine Micropaleontology 63, 91-110.

Gökaşan, E., Algan, O., Tur, H., Meriç, E., Türker, A., Şimşek, M., 2005. Delta formation at the southern entrance of Istanbul Strait (Marmara sea, Turkey): a new interpretation based on high-resolution seismic stratigraphy. Geo-Marine Letters 25, 370-377.

Görür, N., Çagatay, M.N., Emre, Ö, Alpar, B., SakInç, M., Islamoglu, Y., Algan, O., Erkal, T., Keçer, M., Akkök, R., Karllk, G., 2001. Is the abrupt drowning of the Black Sea shelf at 7150 yr a myth? Marine Geology 176, 65-73.

Hiscott, R.N., Aksu, A.E., Mudie, P.J., Marret, F., Abrajano, T., Kaminski, M.A., Evans, J., Çakiroglu, A.I., Yasar, D., 2007. A gradual drowning of the southwestern Black Sea shelf: evidence for a progressive rather than abrupt Holocene reconnection with the eastern Mediterranean Sea through the Marmara Sea Gateway. Quaternary International 167-168, 19-34.

Hiscott, R.N., Aksu, A.E., Mudie, P.J., Marret, F., Abrajano, T., Kaminski, M.A., Evans, J., Çakiroglu, A.I., Yasar, D., 2010. Corrigendum to "A gradual drowning of the southwestern Black Sea shelf: evidence for a progressive rather than abrupt Holocene reconnection with the eastern Mediterranean Sea through the Marmara Sea gateway" [Quaternary International, 167-168 (2007) 19-34]. Quaternary International 226160.

Kwiecien, O., Arz, H., Lamy, F., Wulf, S., Bahr, A., Röhl, U., Haug, G.H., 2008. Estimated reservoir ages of the Black Sea since the last glacial. Radiocarbon 50, 99-118.

Lambeck, K., Sivan, D., Purcell, A., 2007. Timing of the last Mediterranean Sea - Black Sea connection from isostatic models and regional sea-level data. In: YankoHombach, V.V., Gilbert, A.S., Panin, N., Dolukhanov, P.M. (Eds.), The Black Sea Flood Question: Change in Coastline, Climate and Human Settlement. Springer Heidelberg, pp. 797-808.

Lamy, F., Arz, H.W., Bond, G.C., Bahr, A., Pätzold, J., 2006. Multicentennial-scale hydrological changes in the Black Sea and northern Red Sea during the Holocene and the Arctic/North Atlantic Oscillation. Paleoceanography 21. doi:10.1029/2005PA001184 PA1008.

Lane-Serff, G.F., Rohling, E.J., Bryden, H.L., Charnock, H., 1997. Postglacial connection of the Black Sea to the Mediterranean and its relation to the timing of sapropel formation. Paleoceanography 12, 169-174.

Lericolais, G., Bulois, C., Gillet, H., Guichard, F., 2009. High frequency sea level fluctuations recorded in the Black Sea since the LGM. Global and Planetary Change 66, 65-75.

Lericolais, G., Guichard, F., Morigi, C., Minereau, A., Popescu, I., Radan, S., 2010. A post younger dryas Black Sea regression identified from sequence stratigraphy correlated to core analysis and dating. Quaternary International 225, 199-209.

Lericolais, G., Popescu, I., Guichard, F., Popescu, S.M., 2007. A Black Sea lowstand at $8500 \mathrm{yr}$ B.P. indicated by a relict coastal dune system at a depth of $90 \mathrm{~m}$ below sea level. Geological Society of America Special Papers 426, 171-188.

Major, C., Ryan, W., Lericolais, G., Hajdas, I., 2002. Constraints on Black Sea outflow to the Sea of Marmara during the last glacial-interglacial transition. Marine Geology 190, 19-34

Major, C.O., Goldstein, S.L., Ryan, W.B.F., Lericolais, G., Piotrowski, A.M., Hajdas, I., 2006. The co-evolution of Black Sea level and composition through the last deglaciation and its paleoclimatic significance. Quaternary Science Reviews 25, 2031-2047.

Mangerud, J., 1972. Radiocarbon dating of marine shells, including a discussion of apparent age of recent shells from Norway. Boreas 1, 143-172.

Marret, F., Mudie, P., Aksu, A., Hiscott, R.N., 2009. A Holocene dinocyst record of a two-step transformation of the Neoeuxinian brackish water lake into the Black Sea. Quaternary International 197, 72-86.

Marret, F., Mudie, P., Aksu, A., Hiscott, R.N., 2010. Corrigendum to "A Holocene dinocyst record of a two-step transformation of the Neoeuxinian brackish water lake into the Black Sea" [Quaternary International, 197 (2009) 72-86]. Quaternary International 226, 161.

Mudie, P.J., Rochon, A., Aksu, A.E., Gillespie, H., 2002. Dinoflagellate cysts, freshwater algae and fungal spores as salinity indicators in late Quaternary cores from Marmara and Black seas. Marine Geology 190, 203-231. 
Mudie, P.J., Rochon, A., Aksu, A.E., Gillespie, H., 2004. Lateglacial, Holocene and modern dinoflagellate cyst assemblages in the Aegean-Marmara-Black Sea corridor: statistical analysis and re-interpretation of the early Holocene Noah's Flood hypothesis. Review of Palaeobotany and Palynology 128, 143-167.

Myers, P.G., Wielki, C., Goldstein, S.B., Rohling, E.J., 2003. Hydraulic calculations of postglacial connections between the Mediterranean and the Black Sea. Marine Geology 201, 253-267.

Oaie, G., Melinte-Dobrinescu, M.C., Holocene litho- and biostratigraphy of the NW Black Sea (Romanian shelf). Quaternary International, Corrected Proof, in press. doi:10.1016/j.quaint.2009.12.014.

Reimer, P.J., Baillie, M.G.L., Bard, E., Bayliss, A., Beck, J.W., Blackwell, P.G., Bronk Ramsey, C., Buck, C.E., Burr, G.S., Edwards, R.L., Friedrich, M., Grootes, P.M., Guilderson, T.P., Hajdas, I., Heaton, T.J., Hogg, A.G., Hughen, K.A., Kaiser, K.F. Kromer, B., McCormac, G., Manning, S., Reimer, R.W., Richards, D.A., Southon, J.R., Talamo, S., Turney, C.S.M., van der Plicht, J., Weyhenmeyer, C.E., 2009. IntCal09 and Marine09 radiocarbon age calibration curves, 0-50,000 Years cal BP. Radiocarbon 51, 1111-1150.

Ross, D.A., Degens, E.T., 1974. Recent sediments of Black Sea. In: Degens, E.T., Ross, D.A. (Eds.), The Black Sea: Geology, Chemistry, and Biology. American Association of Petroleum Geologists, Tulsa, pp. 183-199.

Ross, D.A., Degens, E.T., Macllvaine, J., 1970. Black Sea: recent sedimentary history. Science 170, 163-165.

Ryan, W.B.F, 2007. Status of the Black sea flood hypothesis. In: Yanko-Hombach, V. Gilbert, A.S., Panin, N., Dolukhanov, P.M. (Eds.), The Black Sea Flood Question: Changes in Coastline, Climate and Human Settlement. Springer, New York, pp.63-88.

Ryan, W.B.F., Major, C.O., Lericolais, G., Goldstein, S.L., 2003. Catastrophic flooding of the Black sea. Annual Review of Earth and Planetary Sciences 31, 525-554.

Ryan, W.B.F., Pitman, W.C., 1998. Noah's Flood: The New Scientific Discoveries about the Event that Changes History. Simon \& Schuster, New-York.

Ryan, W.B.F., Pitman, W.C., Major, C.O., Shimkus, K., Moskalenko, V., Jones, G.A. Dimitrov, P., Gorür, N., Sakinç, M., Yüce, H., 1997. An abrupt drowning of the Black Sea shelf. Marine Geology 138, 119-126.
Schrader, H.-J., 1979. Quaternary Paleoclimatology of the Black Sea basin. Sedimentary Geology 23, 165-180.

Shcherbakov, F.A., Babak, Y.V., 1979. Stratigraphic subdivision of the Neoeuxinian deposits in the Black Sea. Oceanology 19, 298-300.

Soulet, G., Delaygue, G., Vallet-Coulomb, C., Böttcher, M.E., Sonzogni, C., Lericolais, G., Bard, E., 2010. Glacial hydrologic conditions in the Black Sea reconstructed using geochemical pore water profiles. Earth and Planetary Science Letters 296, 57-66.

Stein, M., Migowski, C., Bookman, R., Lazar, B., 2004. Temporal changes in radiocarbon reservoir age in the Dead Sea Lake Lisan system. Radiocarbon 46, 649-655.

Stoffers, P., Degens, E.T., Trimonis, E.S., 1978. Stratigraphy and suggested ages of Black Sea sediments cored during Leg 42B. In: Ross, D.A., Neprochnov, Y.P., et al. (Eds.), Initial Reports of the Deep Sea Drilling Project. U.S. Government Printing Office, Washington, pp. 483-488.

Stuiver, M., Polach, H.A., 1977. Discussion reporting of ${ }^{14} \mathrm{C}$ data. Radiocarbon 19 355-363.

Suess, E., Revelle, R., 1957. Carbon dioxide exchange between the atmosphere and ocean and the question of an increase of atmospheric $\mathrm{CO}_{2}$ during the past decades. Tellus 9, 18-27.

Turney, C.S.M., Brown, H., 2007. Catastrophic early Holocene sea level rise, human migration and the Neolithic transition in Europe. Quaternary Science Reviews 26, 2036-2041.

Yanko-Hombach, V., Gilbert, A.S., Panin, A.V., Dolukhanov, P.M. (Eds.), 2007. The Black Sea Flood Question: Changes in Coastline, Climate, and Human Settlement. Springer, New York.

Yanko-Hombach, V., 2007. Controversy over Noah's Flood in the Black Sea: geological and foraminiferal evidence from the shelf. In: Yanko-Hombach, V.V. Gilbert, A.S., Panin, N., Dolukhanov, P.M. (Eds.), The Black Sea Flood Question. Springer, Heidelberg, pp. 149-203.

Zhou, A.-f., Chen, F.-h., Wang, Z.-l., Yang, M.-l., Qiang, M.-r., Zhang, J.-w., 2009. Temporal change of radiocarbon reservoir effect in Sugan Lake, northwest China during the Late Holocene. Radiocarbon 51, 529-535. 